\title{
The Typology of Religious Extremism
}

\author{
Ádám Rixer \\ Károli Gáspár University of the Reformed Church in Hungary, \\ Faculty of Law. Hungary
}

\section{INTRODUCTION}

The issue of religious extremism is typically addressed in the international literature from the perspective of various forms of religious fanaticism ${ }^{1}$ and terrorism, ${ }^{2}$ and based on the "traditional" problems related to religious sects. However, few works have gone beyond the definition of extremism and its main forms of practical implementation to provide a sophisticated system of criteria and offer an exhaustive typology.

This being so, the aim of the present work is to fill in this gap, adopting a three-element structure to set up a typology that groups the various instances of extreme religious activity. This study does this by presenting the realities of a particular state (Hungary) and giving examples of each type of extremist activity where possible - fortunately, due to the complete absence of certain types of violent, religiously motivated phenomena, we could not find any Hungarian examples for some extremist activities. These examples must, of course, be incorporated into the Hungarian context, and therefore this paper also outlines the main contours of Hungarian regulations on religious affairs, the developments that have taken place in recent decades, and the causes behind any major changes.

This work primarily applies the approaches and methods of legal studies and sociology, but also makes use of the views and findings of political science and other fields, and the results of this paper can thereby be considered to have come from a consciously complex approach.

\section{THE POSSIBILITIES OF DEFINITION}

The first question we need to ask and respond to is: compared to what can something be described as "extreme," and whose position is decisive in this matter, accepting that it is obviously worth avoiding extremely relativistic approaches. ${ }^{3}$ The starting point for this study is a consciously state-centred definition: from the state's perspective - in our case, Hungary"extreme" is what the majority considers to be extreme, ${ }^{4}$ but given that state-level religious extremism exists as well (most notably ISIS), we can define "extremism" in relation to the usual

\footnotetext{
${ }^{1}$ Sam Cherribi, "Bad Faith: The Danger of Religious Extremism by Neil J. Kressel; Faith-based Radicalism: Christianity, Islam and Judaism between Constructive Activism and Destructive Fanaticism by Christine Timmerman, Dirk Hutsebaut, Sara Mels, Walter Nonneman, Walter Van Herk: Review", Political Psychology 30, no. 2 (2009): 319-323; and Laurence R. Iannaccone, "Religious Extremism: Origins and Consequences," Contemporary Jewry 20, no. 1 (1999): 8-29.

2 Julia Valerijevna Tusckhova, "ISIS and Al-Qaeda as the Determinants of Religious Extremism in the UK," Society: Politics, Economics, Law 6, no. 8 (2017): 1-4.

${ }^{3}$ One trap in this circle is when we declare that all the religious phenomena are necessarily "extreme," given that their essence (or at least the conceptual seed in which they are rooted) is always the separation and the "lack of self-restraint". This type of relativization and absolutizing aspiration must obviously be taken into account, but even the partial acceptance of this position does not render any conscious systematization of the phenomena unnecessary. Charles S. Liebman, "Extremism as a Religious Norm," Journal for the Scientific Study of Religion 22, no. 1, (1983): 75-86.

${ }^{4}$ From a majority standpoint, assuming a democratic basic structure, we mean some kind of scaled and general approach regarding the central and typical views of the political, professional, and scientific elite and of the media, as expressed in the public sphere.
} 
phenomena, institutionalised practices, and otherwise accepted religious traditions of the majority or of the incorporated church that is characteristic in a given area or group of states, or to a specific "cultural sphere". Doing so will increase objectivity in this examination of

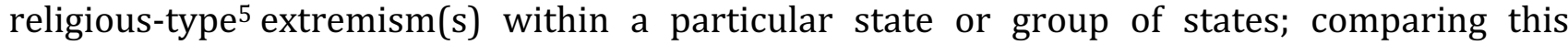
narrower approach to extremism to dominant trends in world religions in general or those that are dominant in a particular geographical area will ensure the presence of a type of control function.

When the Hungarian legislature defines the concept of "religious activity," it provides both a positive definition and a more restrictive negative one, the latter clarifying some of the aspects of the former. ${ }^{6}$

Similarly to the former concept, "religious extremism" can have a negative and a positive definition; the negative definition details the phenomena that may be associated with a religion and even with its institutions, but cannot be considered religious or to have a religious nature, while the positive definition attempts to list in an exhaustive manner the main (domestic) manifestations of religious extremism.

A negative definition of "religious extremism" should include, for example, right violations that do not follow from the official teachings of the given religion, but are rather the results of human omissions caused by a procedural error in the registration process. Similarly, it cannot be considered religious extremism if, for example, a theft occurrs at a religious event if this cannot be considered a generalisable phenomenon resulting from the "essence" of the given religious community. Another potentially problematic issue would be to conclude that the activity or teaching of a particular church or religious community is of an extreme nature in general as a result of any opinions expressed by or wrongdoing committed by the leaders of that church or a larger community of churches; that is, a "bad" or "guilty" leader or misleading practice in itself cannot be said to constitute "religious extremism". In this regard, we must also emphasise the fact that even if a religion-based, socially recognized, but non-majority narrow group norm can in some cases be logically linked with concrete rights violations (for example, the institutional norm of celibacy may be linked with the cases of child sexual abuse committed by people living in celibacy), this does not necessarily mean that the religious community itself

\footnotetext{
5 This paper does not deal with the traditional notion of religion; we understand religion as nothing more than a kind of institutionalised, organized, and legally perceivable objectification of a religious belief that is specific to the concept of religion. ${ }^{6}$ Art. 6 par. (3) - (4) of Act CCVI of 2011 on the Right to Freedom of Conscience and Religion and the Legal Status of Churches, Denominations and Religious Communities (hereinafter referred to as Act CCVI of 2011) - reads as follows:

„(3) Religious activities are activities linked to a worldview which is directed towards the transcendental, has a system of faithbased principles, the teachings of which are directed towards existence as a whole, and which embraces the entire human personality through specific codes of conduct that do not offend morality and human dignity.

(4) The following shall not be considered as religious activities per se:

a) political and lobbying activities;

b) psychic or parapsychic activities;

c) medical activities;

d) business and entrepreneurial activities;

e) instructive activities;

f) educational activities;

g) higher educational activities;

h) healthcare activities;

i) charity activities;

j) family, child or youth protection activities;

k) cultural activities;

l) sports activities;

m) animal protection, environmental protection or nature conservation activities;

n) data control activities, which go beyond data processing necessary for faith-based activities;

o) social work activities."
} 
is considered to be "extreme." This is especially true if, as in the example given here, the group norm is not an element of the "essence of the given religious viewpoint," or if the certain religious community itself takes action against the harmful implications of the given institution, or against the particular abusive phenomenon. ${ }^{7}$

With regard to the positive definition, it is worth noting that only extensive and generalisable practices and phenomena can be considered extremist, and it is generally not appropriate to include isolated and sporadic practices that cannot be attributed to a certain religion, and that cannot be derived from the teachings of the given religion (or religious movement). The aspects that facilitate the grouping of the extreme phenomena, and thereby have an important role in this paper, are as follows:

a) whether the norms that are accepted by the majority of the society and are violated by the extremist activity are legal norms or non-legal social norms;

b) whether the "extreme" behaviour has a negative impact on the community outside the religious group, or the negative impact predominantly affects the religious group itself;

c) whether or not it involves violence.

For the sake of clarity and simplicity, in this paper we will limit our analysis to the above elements and will primarily shape our suggested typology on this basis. Of course, this paper is only a first-sight inspection, an attempt to establish a primary typology; further work would benefit from the inclusion of a number of additional considerations, such as "isolating" extreme religious activities as an independent aspect. This would help to examine the extent of the extreme practices, whether they are applicable beyond country and continental borders, among other possible items of interest. Furthermore, an equally interesting analysis would be an international comparison based on the aspects described in this work, or an examination of individual states (in our case, that of Hungary), taking in consideration the extent and way in which the state is biased with respect to one or another religion, and analysing whether the religious policy of the state in question can be regarded as supportive or obstructive in terms of a religious phenomenon that can otherwise be regarded as "extreme", according to a yardstick designed specifically. Such an approach would obviously go far beyond the traditional divisions, according to which typologies are elaborated based on aspects such as the character and direction of the state attitude towards religion, the intensity of the state presence, and the degree of institutional interconnection.

Hereinafter, for Hungary, we will illustrate the broader social and narrower public policy contexts of religious phenomena, describe in particular the provisions of major normative acts and related jurisprudence practices, and present some earlier examples of "extreme" religious phenomena that appeared after the collapse of the communist regime in 1990.

\footnotetext{
7 The encountering and confrontation with this phenomenon in the Catholic Church had and has several waves. On February 69, 2012, an international meeting was held in Rome with the participation of bishops and monastic religious leaders from various dioceses of the world to combat the sexual abuse of children committed by official representatives of the Church, and to help the victims. In this regard, see: Stephen J. Rosetti, "Bátor szembenézés: Hatékony fellépés a gyermekek szexuális kihasználóival szemben" [Brave facing: An Effective action against sexual exploitation of children], Korunk 32, no. 4 (2012): 99106. Regarding the practice of individual countries (and their member churches) see: Jo Renee Formicola, "Recalibrating U.S. Catholic Church-State Relations: The Effects of Clerical Sexual Abuse," Journal of Church \& State 58, no. 2 (2016): 307-330; and Kathleen McPhillips, "The Church, the Commission and the Truth: Inside the NSW Special Inquiry into Child Sexual Abuse," Journal for the Academic Study of Religion 29, no. 1 (2016): 30-51. The starting point in almost every case for these articles is that in addition to the ecclesiastical leaders, the public authorities have also contributed decisively to the covering-up of these events for decades.
} 


\section{The main legal framework}

\section{THE SOCIAL AND LEGAL ENVIRONMENT IN HUNGARY}

After the fall of the Iron Curtain in 1990, Hungary, as other countries in Central and Eastern Eastern Europe ${ }^{8}$, adopted a democratic state structure characterised by the rule of law and a new, rapidly developing political system that replaced the former one-party, state-socialistic (communist), and authoritarian system. In addition to the liberalisation and privatisation associated with the emergence of a market economy, various kinds of compensatory economic phenomena and institutions (such as Agency for Restitution) appeared. Of course, this led to radical changes in the relationship between church and state; in addition ${ }^{9}$ to the symbolic changes, the legal status of the various churches and religious communities in the country, their rights and their ability to collaborate in the provision of public duties (public services), and their economic possibilities also changed significantly. One important aspect in this regard was that the various churches were no longer institutionally subordinated to the state organs.

According to the Fundamental Law of Hungary, the state and religious communities operate separately, making religious communities independent. ${ }^{10}$ This is also confirmed by the fact that the state cannot operate or create a body for the management and supervision of religious communities. Here, the word "separate" is more appropriate than "divided" or "disunited" because it clearly indicates that this legal situation is not the result of the goodwill of the state, or its active intervention.

At the same time, this separation does not disallow material or other support of religious communities by the state, nor even stipulate that the state treats (supports) different religious communities according to certain defined aspects in different manners and measures. The fundamental principle that has been in place since the regime change of 1990 is that the state can take into account the characteristics of religious communities that distinguish these entities from other social organisations, associations, interest-representation bodies, and so on, and can even individually enter into different agreements and forms of cooperation with them (such as granting them money or real estate) that serve the public interest, thereby contributing to the realisation of their constitutional fundamental rights. According to Decision 4/1993. (II.12) of the Constitutional Court, treating different religious communities (churches) differently may affect freedom of religion in the community, such a distinction would not necessarily violate the Constitution if based on actual social differences. Traditionally, such differences may be observed due to the size of religious communities, their degree of involvement in public services, and their active social presence. ${ }^{11}$

According to the Act CCVI of 2011, the two basic types of religious communities today are churches recognised by the Parliament (incorporated churches) and religious organisations (associations) that engage in religious activity. However, this practical framework for religious activities does not only serve the institutionalised religious bodies acknowledged in the applicable law; in Hungary, groups that are informally organised and that function without any formalities can also benefit from the freedom to practice their religion. In short, fully informal

\footnotetext{
8 Silvio Ferrari and W. Cole Durham eds., Law and Religion in Post-Communist Europe (Dudley, Mass.: Peeters, 2003).

${ }^{9}$ In many former communist countries "in the context of the demand for the new Constitutions, the need to mention Christianity (in some cases the Catholic Church) in the Constitution was emphasized, and it was even stated that the text(s) should begin with an Invocatio Dei." Krystyna Daniel and W. Cole Durham, "Religious identity as a component of national identity," Fundamentum 1, no. 2 (1997): 6. The latter requirement was met in Hungary's new constitution (Fundamental Law of Hungary), which entered into force on January 1, 2012; the text begins with the sentence: “God, bless the Hungarians!"

10 Art. VII. par. (3) of the Fundamental Law of Hungary.

11 Schanda Balázs, "A vallásszabadság és a lelkiismeret szabadsága" [Freedom of religion and freedom of conscience], in Alkotmányjog - Alapjogok [Constitutional Law - Fundamental Rights], eds. Schanda Balázs and Balogh Zsolt (Budapest: PPKE JÁK, 2011), 163-64.
} 
religious movements or periodically functioning local religious groups are equally protected by the law as organisations that exist as legal entities. ${ }^{12}$

The most significant difference between incorporated churches and associations is that Parliament decides on the possible recognition of a church, ${ }^{13}$ while the registration of a religious association pertains to the exclusive jurisdiction of the Budapest-Capital Regional Court. ${ }^{14}$ As of the beginning of 2018, there are 32 incorporated churches recognised in Hungary via Act CCVI of 2011, instead of the 230 churches recognised before 2012.

According to Article 9 par. (1) and Article 12 par. (1) of the former Act IV of 1990 on Freedom of Conscience and Religion, the registration of a church was decided by the county court competent for the seat of the church, or by the Municipal Court of Budapest in a non-litigious procedure. For over twenty years before 2012, the registration procedure for churches was entirely formal, mainly because the courts did not carry out substantive investigations after the applicants had made their statements and submitted the compulsory documents into the authenticity of the content of the documents or the goals and aims of the organisation. In other words, if seemingly legitimate and at least superficially religious content could be found on the documents and they were submitted with the appropriate formalities, the registration was in the vast majority of cases done automatically. However, after 1990, winning "church" status, as opposed to being merely a religious organisation, meant serious tax- and other rights-related entitlements. Given that in after 1990, it was enough to have 100 members to claim "church" status (as opposed to the compulsory 10 members needed for a religious "organisation", i.e. association), it is clear why almost all religious communities pursued ecclesiastical status. It was deliberately made very easy to establish a religious "organisation" after 1990, and this opened the gate to abuses in the form of organisations that used a religious framework as a disguise for other activities.

Legislation concerning religious communities often enters the public eye after news is spread of certain seemingly extreme religious practices, and the lawmakers try to implement the necessary changes. ${ }^{15}$ After the regime change in Hungary, several waves of problems and abusive practices emerged with regard to issues such as tax exemptions and milder settlement rules for religious activities, easier ${ }^{16}$ visa regimes for foreign clergymen, tax exemptions for the

\footnotetext{
12 Art. 1. par. (1)-(3) of Act CCVI of 2011.

${ }^{13}$ According to Art. 6 par. (1) of Act CCVI of 2011, a two-tiered classification consisting of "religious organisations" and "incorporated churches" is established, the latter being churches recognised by Parliament, while the former including registered religious associations. A church recognised by the Parliament is considered to be an incorporated church. The churches recognised by Parliament are included in the Annex of Act CCVI of 2011.

14 Art. 9/B. par. (1) of Act CCVI of 2011. An important issue here is that the legislature makes the registration of religious associations easier due to the fact that after an application for registration, the court only examines whether:

a) the organisation's representatives have stated that the organisation is founded for the purpose of religious activity;

b) the activity to be developed by the organisation does not conflict with Article 6 par. (4) and (5) of Act CCVI of 2011;

c) at least ten members have established the organisation and have adopted its statute;

d) the members of the organisation are only natural persons, and the statute does not allow for legal persons to become members; and

e) the name of the organisation corresponds to the principles of exclusivity and uniqueness and is adequate from a linguistic viewpoint.

The Budapest-Capital Regional Court can reject the application for registration only if the organisation does not comply with one or more of the conditions set out above.

15 Daniel and Durham, "Religious identity as a component of national identity," 6.

16 The production and sale of booklets, souvenirs, and other items necessary for religious practices is not considered an economic-entrepreneurial activity; the significance of this regulation is that a church is exempted from its tax and contribution obligations for this kind of activity. An attempt has even made to organise a new church in order to sell non-religious objects as religious ones: The Motorcycle Association of Győrujbarát sought to establish a church around a shop selling motorcycle products so that each item sold in the shop be considered a religious object, thus leading to substantial financial gain. Goods imported duty-free as religious objects could also have been sold as tax-free items. On their website, one could read the
} 
"offertory box," and in connection with church foundations helping people to avoid military service. However, the authorities only took measures with regard to these phenomena in the most intractable cases such as the famous Gyurcsok József case, ${ }^{17}$ in which the public prosecutor's office undertook far-reaching action.

The first attempt to impose more severe restrictions on religious bodies - Act CLXXV of 2011 on the Right to Freedom of Conscience and Religion and on the Status of Churches, Denominations and Religious Communities - was declared unconstitutional by the Constitutional Court because it infringed on the public law, and was therefore annulled.18 This decision of the Constitutional Court ${ }^{19}$ was based, among other things, on the fact that the Act had no procedural deadlines and explicit decision-making obligations for Parliament, and lacked a method by which petitioners could appeal. All things considered, the law was extremely unprepared, and no prior impact assessment was conducted. ${ }^{20}$

The subsequently adopted new act [Act CCVI of 2011] eliminated several procedural problems, but some of the problems with the content that had given rise to serious debate remain, primarily due to the fact that the article regarding the approval of the Parliament remains in force. Furthermore, in spite of the fact that Article 14 of the given act stipulates nine exhaustive recognition criteria; of these, for the first six, the decision of the minister is (more or less) binding for the Parliament, while judgment regarding the last three criteria ("whether or not they can be proved") is fully dependent on Parliament. This absolute discretion this approach allows is in no way affected by the fact that the rejection of a request must be justified by a resolution by Parliament. Similarly, the fact that the religious organisation that applies to be incorporated as a church can request the revision of a parliamentary decision from the Constitutional Court does not entail content control because the Constitutional Court will only review the lawfulness of the parliamentary procedure for the recognition of the "organisation" as a "church"; it will not analyse whether "the organization can actually prove its intention to cooperate for the purposes of the Community and its ability to sustain this aim for a long time". ${ }^{21}$

To summarise the above-mentioned issues: the fundamental dilemma was (and partially still is) the fact that tightening the law and the legal procedure relying on the law (e.g., with regard to the substantive examination of the religious purpose) must have been done in a manner

following text for quite some time: "members of our association each year give thanks to the Holy God of Carburettor and his Child St. Injector." Rixer Ádám, “A vallás fogalmáról” [About the concept of religion], Jogelméleti Szemle 12, no. 4 (2011): 8.

17 The distance healing by that person was not included in the charter of the church (Church of Universal Love), and this was the object of the proceedings brought before the Pest County Court.

18 The apparent cause of the implementation of this law - which generated significant media coverage - was a practice that became very popular towards the end of the 2000s through which private homes for elderly people were, mostly with the involvement of the elderly people living there, but without actual religious activity, transformed into churches, thereby obtaining the supplementary normative support for churches.

19 Details of the decision can be read in Decision 164/2011. (XII. 20.) of the Constitutional Court.

20 The preliminary impact assessments adapted to the final textual variants of Act C. and CCVI. of 2011 would have been relevant because they could have justified certain fears - which were the subject of a great deal of disputes in Parliament for over a decade and a half - about how to save Hungarian society from the effect of the destructive activity of sects that 'kidnapped children, destroyed families, took possession of misfortunate people, encouraged their members to commit collective suicide, and promoted ritual human sacrifice'. One of the decisive reasons behind the lack of preliminary impact assessments was that these fears may not have been real. Indeed, a genuinely objective survey would probably underline that the vast majority of small churches that became religious organizations in 2012 play a significant role today in Hungary in the strengthening of social cohesion and solidarity and have a slight but tangible impact on the renewal of societal fabric. Rixer Ádám, “A hatásvizsgálatok jelentősége és egyes szempontjai a vallási szervezetek szabályozása körében” [The importance of impact assessments and some aspects of regulating religious organizations], Kodifikáció 2, no 1 (2013): 95.

${ }^{21}$ Art. 14 subpar. (i). 
that, within reasonable and well-interpretable expectations, serves the "public interest," without limiting the practical effectiveness of certain essential rights. ${ }^{22}$

\section{The situation in Hungary from the perspective of financing: the finances and management of religious communities}

The model applied in Hungary until 2012 was one of neutral financing, according to which regardless of its ideological commitment or preferences, the legislature granted "non-historic" Christian churches - or even a non-monotheistic religion - formal and substantive equality, at least as far as elementary framework conditions are concerned such as subsidies, exemptions from certain duties, and certain other benefits. Overall, until the Act CCVI of 2011 entered into force, a neutral financing model prevailed.

The latest law introduced a three-element category system: incorporated churches, religious organisations (associations), and an effectively separate type of religious communities that can enter into an agreement with the Government. This is a financing model based on valueselection that consciously lacks the traditional neutrality of the previous model, given that inter alia, both the acquisition of "church" status (and the subsequent material ${ }^{23}$ benefits obtained) and whether the group will enter into an agreement with the Government are decided by the authorities competent to take the decision (the Parliament and the Government of Hungary), and no substantive remedies are in place for those who seek to dispute the decision. ${ }^{24}$

\section{Assessing the Hungarian model}

In conclusion, we can state that Hungary's model cannot be considered either an 'established church' model or a one of radical separation, but rather a specific transition between the two; that is, a value-based model shaping the relationship between the state and religious

\footnotetext{
22 For example, before the new act(s) had been passed, there was a steady need to ensure the uniformity of the registration procedure and as part of this, only one state body (a court or public administration authority) was to deal with this issue due to the special expertise required. The legislator was able to meet this requirement (i.e. the professional aspect).

23 In addition to the processes regulated by Act XXXII of 1991 on the Settlement of Ownership of Old Church Property, today, the most important rights conferred to churches are the provisions of Act CXVII of 1995 on Personal Income Tax included in Annex no. 1 of the Act, that adjudges the exemptions from taxes and duties of all donations, grants, gifts, and benefits obtained by the church. Such incomes are 1 percent of the personal income tax paid by the private individuals making a tax declaration in this regard; the auxiliary subsidies granted to the social, healthcare, and cultural institutions of the churches, in addition to normative aid; and the existence of central budget appropriations supporting the reconstruction of ecclesiastical buildings and other ecclesiastical investments, or the supplementation of the income of pastors serving in small settlements in the form of additional salaries provided by the state.

24 On April 8, the Grand Chamber of the European Court of Human Rights (ECtHR) ruled against Hungary in a 5:2 ratio in the case of 17 Hungarian religious denominations that on January 1, 2012 and March 1, 2012 lost their status as registered churches as a result of The Hungarian Act CCVI of 2011. The ECtHR had come to the conclusion that the Act CCVI of 2011 violated the applicant churches' rights to freedom of thought, conscience and religion, and freedom of association protected by Articles 9 and 11 of the European Convention on Human Rights (the Convention) because the law recognised only the church status of "the incorporated churches" listed in its annex, while the other organisations with former "church" status were classified as "associations," while in the same time, competence for the registration of churches was taken from the courts to Parliament. Analysing the case and the arguments, the ECtHR explained that: in order to ensure freedom of religion and conscience, the state should remain independent and must create impartial rules for religious communities. In its opinion, by bringing into its own jurisdiction the decision as to which religious communities can be declared churches, the Hungarian Parliament infringed Article 9 of the Convention (the court referred to the case Metropolitan vs. Bessarabia). The ECtHR further examined whether the provisions of Article 9 (2) were being met; i.e., if the restriction was established by law, and if it was made in the interest of public security, public order, public health, public morality, or the rights and freedoms of others. The court found that Act CCVI of 2011 is restrictive. While it found that the prevention of the abuse of public money is likely to stand, being a matter of the public interest, it concluded that the restriction is not proportionate to the objective pursued, given that the action of the Hungarian state is exaggerated and excessively strict. However, Strasbourg did not cast doubts on the public interest: the ECtHR only found it justified to adopt a milder, more co-operative, and more independent parliamentary regulation. Subsequently, on June 28, the ECtHR awards pecuniary and non-pecuniary damages for the infringements previously found in the case of several complainants of between 40,000 and 140,000 euros. Source: Rixer Ádám, "Az állam és a vallási közösségek kapcsolata a mai Magyarországon. A vallási közösségek nyilvántartása és pénzügyei a jogi szabályozás tükrében" [The Relationship of the State with the Religious Communities in Present Day Hungary Records and finances of religious communities in the light of legal regulations], Államtudományi Múhelytanulmányok 2, no. 1 (2017): 17.
} 
communities. A distinguishing feature of this model is that in contrast to the requirement of neutrality, which was met by the former legislation that ensured the applicability of these conditions, it emphasises the values and political considerations both in regulation and practice, thus giving extremely far-reaching authority that extends far beyond the typical Hungarian practice to the state bodies, as far as the conferring of "church" status and agreements with the state are concerned.

\section{TYPES OF RELIGIOUS EXTREMISM}

Based on the considerations presented in Chapter 2, the following types of religious extremism can be distinguished with regard to religious communities and practitioners: ${ }^{25}$

I. Religious extremism in certain religious communities that is not of an illegal nature, and does not violate basic norms of the majority society and is not connected with the essential principles of the (world) religion in question. This may include, for example, the occurrence of extreme phenomena in the context of certain ceremonies, or in the practices of members of a religious group (e.g. the Saint Saliva ${ }^{26}$ ). These members are deemed likely to trigger consternation, discouragement, dislike, or pity in members of the majority society, without violating legaltype rules or creating greater "disturbances" with outsiders, particularly because they mainly occur within the given religious entity.

II. Religious extremism within certain religious communities that violates the basic - but not legal - norms of the majority society and also appears outside the religious community. For example, certain rules about clothing may cause indignation or fear in some cultures because for the majority of European society, the burqa, the niqab, or any clothing that covers the whole female body, including the face, is a powerful symbol of the oppression and subjugation ${ }^{27}$ of women (see the European disputes about the burqa). A similar phenomenon is discrimination against women and children, if this is the result of religious beliefs.

Compared to category I, these practices, behavioural patterns, and patterns of religious origin undeniably endanger the established structure of the society, its centuries-old principles, and its sensus communis. Furthermore, the persistence of these apparently cultural differences and the presence of parallel societal patterns will sooner or later make it necessary to launch legal types of regulation according these issues. Assuming a further transformation of the Hungarian population, like some Western European states, the government will eventually be forced to focus on the issue of the burqa and similar garments.

III. Religious extremism within certain religious communities that violates the law and is directed at communities outside the religious community in question. An example of this would be committing suicide bombings for religious reasons. ${ }^{28}$ These phenomena are not features of life in Hungary, but - for example - in December 2017, blue concrete blocks with the text "BRFK"

\footnotetext{
25 We will not analyse here the extreme relation of the state to religion; for criticisms of Hungary, please see the abovementioned aspects.

26 Due to a certain interpretation of verse 6 of Chapter 9 of the Gospel of John ("After saying this, he spit on the ground, made $s$ ome mud with the saliva, and put it on the man's eyes") in some charismatic religious communities, there is practice whereby $t$ he pastor or another person spits on someone (with his consent) for 'healing' purposes.

${ }^{27} \mathrm{~A}$ rule on clothing might, of course, have legal implications as well. Thus, for example, the hooligans of AIK Solna - a Swedish first-class football club - appeared in the club stadium in April 2017 wearing a niqab (a women's scarf worn in Islamic areas) because a Swedish legal source that entered into force in March 2017 prohibited only the wearing of ski masks (balaclavas), but expressly points out that the wearing of headscarves and veils for religious reasons is not prohibited. Access: http://index.hu/sport/futball/2017/04/04/betiltottak_a_maszkot_nikabban_mentek_meccsre/

28 See, for example: Scott Ashworth, Joshua D. Clinton, Adam Meirowitz and Kristopher W. Ramsay, "Design, Inference, and the Strategic Logic of Suicide Terrorism," The American Political Science Review 102, no. 2 (2008): 269-273.
} 
(Budapest Police Headquarters) were erected at the various Christmas markets in Budapest; these were intended to dissuade anyone from committed a mass terrorist attack in a vehicle like that which took place in Berlin in December 2016. This and other examples reveal that Hungarian law enforcement agencies are increasingly engaging in preventive behaviour in connection with certain extremist activities.

IV. Religious extremism (within certain religious communities) that violates the law and is also directed towards communities outside the religious community, but is not violent in nature. Rather than religious activity, this category primarily focuses on economic activity such as the abuse of tax allowances and subsidies, and the misuse of personal data. One recent example occurred in October 2017, when Hungary's data protection authority fined the Church of Scientology in Hungary and its headquarters 20 million forints each for the abuse of personal and other data. Here, the National Investigation Bureau of the Riot Police (KR NNI) conducted investigations into an unknown offender over the misuse of personal data and on suspicion of having committed other crimes; on October 17, against a backdrop of sizeable media coverage, this body conducted a search at the Church of Scientology in Budapest.

V. Extremism with a religious origin that violates the legal-type norms of the majority society and is prevalent within the given religious community. An example of this type of extremism in Hungary would be the anathema ritual, in which a former member of certain religious community is cursed by said community in his/her absence. Later, he/she might even be assaulted for allegedly 'pedagogical' purposes. An even more extreme example that sometimes leads to death is the phenomenon of Breatharianism, in which (typically) children and women are forced to refuse food and attempt to survive on sunlight only. ${ }^{29}$

VI. Extremism that violates the legal-type norms of the majority society but does not necessarily have a religious origin, and mostly takes place within the given religious community. In these cases, while religion is generally only an excuse, the individual, group, or leadership interests must at least partially be based on religious principles and rules and are often accompanied by emotional pressure. Members must give up their assets in favour of their community and the community interferes deeply with members' private lives. A typical characteristic of this extremism is that neither the member's nor the leader's behaviour is unlawful (because it is legal to hand over one's property to anyone, or to permit anyone to interfere with one's life, and one can ask someone to support certain common goals with their wealth). In some cases, the decision (consent) of the member is based on a voluntary, personal belief and positive commitment, such as on the will of a healthy, autonomous personality. In these cases, the central question concerns whether this relationship involves emotional pressurising or the creation of a sense of guilt, and if the extent and nature of the possible deceit meets the sui generis character of deceit and coercion. It is no coincidence that these cases often do not reach the authorities since in the vast majority of cases, the acting organ needs to embark on a formal procedure to investigate and legally qualify consciences, intentions, motivations, and religious convictions, in most cases without any other tangible evidence.

VII. Theological extremism: an opposing argument or system of views that expresses itself in a matter that is relevant to a particular religion or society but goes against the opinion or any other "common" theological position(s) of the majority of the parishioners of the (world) religion in question. Such extremes can in practice be linked to those of category I, but the people who carry out these extreme practices are not necessarily aware of the exact theological

${ }^{29}$ In 2008 in Budapest, a woman died due to her Breatharianism, while five years later in Agárd a child also lost his life due to this practice. 
background of their behaviour, and category VII does not focus on the practice based on theology, but rather on the debate - which is to some degree professional or scientific - that arises in connection with a religious doctrine, and as a result a view becomes "extreme" in the "canon".

Looking at these seven points, it is obvious that in Hungary as well as in most democratic states with the rule of law, open legislative and law enforcement action is usually limited to the cases described in category III. Although the situations described in categories II and IV would make legal action necessary, in practice we find that primarily due to political reasons, direct or indirect action does not occur, or only in case of an escalation of the situation in the form of a process following the events, and often becomes subject to internal contradictions. With regard to category II, the case of homes for the elderly that became churches based on a strictly formal procedure that lacked any act of justification - this situation was made possible due to the fact that no prosecution took place - brought into being new law, with legal consequences that affected everybody. And, for category IV, typical examples are the European regulations related to the wearing of the burqa.

In some cases, in categories I and II, a significant issue is the fear of the unknown, revealing the importance of education and sensitisation. ${ }^{30}$ Contemporary public education in Hungary is still more concerned with bauxite mining than Islamic doctrines, cultural features, and religious extremities. Furthermore, there are significant shortcomings and backlogs in the field of education in Hungary.

For categories V and VI, even when such cases occur, there is a great deal of latency and evidence is often hard to come by, so these types of procedures are not usually started; the authorities expressly "show repugnance" towards them. Such legal procedures only take place in a very small number of cases that have already resulted in death or serious health damage (e.g. the case of Breatharians) or evidence of abuse is easily obtainable, such as when the authentication is well-documented. The extremism covered in category VII does not exclude legal implications if the theological position itself is capable of causing unlawfulness, such as if it represents a provocation or incitement.

The above-mentioned issues are also important because they can at least partly explain why despite the large size of the "religious sector" in Hungary, the number of cases brought before the authorities and actually solved is insignificant.

\section{CONCLUSION}

All in all, the particular characteristics of the "religious" sector in Hungary result in the fact that religious extremism as an emphasised phenomenon that, if it required legal intervention, would appear massive or serious in nature, does not or can hardly be said to exist in the country. While there are or may be such cases, their limited numbers can be ascribed to the uncertain limits of freedom of conscience and religion, political fears, the absence of denunciations in these types of cases, the difficulty of finding evidence (e.g. the public reluctance to ask old people living in a nursing home about their religious orientation), in addition to the country's objective social conditions. The fact that religion-based terrorism is not yet present in Hungary is an important public and political issue in the country and maintaining this situation through the effective management of migration and border protection, along with the current religious and ethnic homogeneity, is a major public policy and even a strategic goal in today's Hungary.

30 Sandra Beasley, “Islam’s Silent Majority,” The American Scholar 77, no. 2 (2008): 12. 
An examination of the domestic scholarly literature makes it clear that "extreme" phenomena in Hungary have appeared almost exclusively in the form of political extremism, mainly in connection with national-radical- and national-socialist-type organisations and aspirations, ${ }^{31}$ and in the form of problems related to the "traditional" question related to religious sects. ${ }^{32}$ Moreover, there appears to be a positive relationship between religion and crime in the Hungarian jurisprudential and criminological literature; it is generally acknowledged that religion has a preventative and positive influence, and there is a lack of any descriptions of its harmful results. ${ }^{33}$ In the international literature, however, there is a strong current linked to international networks - and especially to Islamic radicalism - and to separatist aspirations based on ethnical and sometimes religious grounds. ${ }^{34}$ Due to the total lack of Hungarian examples, these latter appear only marginally in the Hungarian scholarly literature.

It is evident, however, that religious extremism rarely "goes alone" in the world; in most cases, religious extremism breeds further "deflections" and confrontations, and also builds itself upon other existing social differences or unhealthy phenomena. ${ }^{35}$

\footnotetext{
${ }^{31}$ See, for example: Boross Zsigmond Attila, “Extrémizmus - terrorizmus, avagy a politikai szélsőség útja a terrorcselekményig Magyarországon" [Extremism - terrorism, or the path of political extremism to terrorist acts in Hungary], Terror \& Elhárítás (Terror \& Combat) 3, no. 3 (2013): 1-19.

32 This includes but is not limited to attempts to underline the diversity of the subject; see, for example, in the Hungarian scholarly literature over the last decades: Lugosi Győző, "Szekták, kultuszok, (már nem is annyira) új vallási mozgalmak: Szcientológia és globalizáció" [Sects, cults, (and not so new) religious movements: Scientology and globalization], Eszmélet 29, no. 2 (2017): 190-211.; Kinda István, "Hívők. Egyház és szekta hatása egy székely falu cigány lakosságára” [Believers. The effect of the Church and of the Sect on the Gypsy population of a Székely village], Mediárium: társadalom - egyház - kommunikáció 6 , 3-4. (2008): 25.; Tarsoly Eszter, "A szcientológia keresztyén szemmel” [Scientology with Christian eyes], Sárospataki füzetek (Booklets of Sárospatak) 15, no. 2 (2011): 135-146.; Papp Ferenc, "Igaz-e, hogy nem szekta a Hit Gyülekezete?" [Is it true that the Faith Church is not a sect?], Távlatok: világnézet, lelkiség, kultúra 4, no. 1 (1996): 470-476.; Mezei Andrea, "Szekta és egyház a rendszerváltás után" [Sect and Church after the change of regime], Társadalmi Szemle (Social Review)49, no. 3 (1994): 44-53.; Shelly Maynard, "Szélsőséges mozgalmak és az egyház Amerikában" [Extreme movements and church in America], Lelkipásztor: evangélikus lelkészi szakfolyóirat (The Pastor) 12, no. 6 (1971): 358-360.

33 See: Forray R. Katalin, “Fiatalkorú bűnözés és vallásosság. Vizsgálatok a bűnöző fiatalok vallásosságáról és a preventív vallási nevelés kilátásai" [Juvenile delinquency and religion. Investigations on the Religion of Criminal Young People and Prospects for Preventive Religious Education], Educatio 1, no. 1 (1992): 158-159. This approach is not just a domestic characteristic, it appears with an emphasis in international literature, too. See, for example: Evelyn L. Lehrer and Carmel U. Chiswick, "Religion as a Determinant of Marital Stability," Demography 30, no. 3 (1993): 385-404; Christopher G. Ellison, "Religious Involvement and Subjective Well-Being," Journal of Health and Social Behaviour 32, no. 1 (1991): 80-99.; E. Wilbur Bock, John K. Cochran and Leonard Beeghly, "Moral Messages: The Relative Influence of Denomination on the Religiosity-Alcohol Relationship," Sociological Quarterly 28, no. 1 (1987): 89-103.; Rodney Stark and William S. Bainbridge, "Towards a Theory of Religion: Religious Commitment," Journal for the Scientific Study of Religion 19, no. 1 (1980): 114-128.

${ }^{34}$ Regarding the latter see: Mariya Y. Omelicheva, "The Ethnic Dimension of Religious Extremism and Terrorism in Central Asia," International Political Science Review/Revue internationale de science politique 31, no. 2 (2010): 167-186.; Angel Rabasa and John Haseman, The Military and Democracy in Indonesia: Challenges, Politics, and Power ( Jakarta: RAND Corporation, 2002).

35 Suzanne J. Piotrowski and Alex Ingrams, "Linking Corruption with Institutional Failure, Terrorism, and Religious Extremism," Public Administration Review 76, no. 2 (2016): 360-363.
} 


\section{Reference list}

Ashworth, Scott, Joshua D. Clinton, Adam Meirowitz and Kristopher W. Ramsay, "Design, Inference, and the Strategic Logic of Suicide Terrorism.” The American Political Science Review 102, no. 2 (2008): 269-273.

Beasley, Sandra, “Islam’s Silent Majority.” The American Scholar 77, no. 2 (2008): 11-18.

Bock, E. Wilbur, John K. Cochran, and Leonard Beeghly, "Moral Messages: The Relative Influence of Denomination on the Religiosity-Alcohol Relationship." Sociological Quarterly 28, no. 1 (1987): 89-103.

Boross Zsigmond Attila, "Extrémizmus - terrorizmus, avagy a politikai szélsőség útja a terrorcselekményig Magyarországon" [Extremism - terrorism, or the path of political extremism to terrorist acts in Hungary]. Terror \& Elhárítás (Terror \& Combat) 3, no. 3 (2013): 1-19.

Cherribi, Sam, “Bad Faith: The Danger of Religious Extremism by Neil J. Kressel; Faith-based Radicalism: Christianity, Islam and Judaism between Constructive Activism and Destructive Fanaticism by Christine Timmerman, Dirk Hutsebaut, Sara Mels, Walter Nonneman, Walter Van Herk: Review." Political Psychology 30, no. 2 (2009): 319-323

Daniel, Krystyna, and W. Cole Durham, "Religious identity as a component of national identity." Fundamentum 1, no. 2 (1997): 6. 5-21.

Ellison, Christopher G., "Religious Involvement and Subjective Well-Being." Journal of Health and Social Behaviour 32, no. 1 (1991): 80-99.

Ferrari, Silvio, and W. Cole Durham, eds., Law and Religion in Post-Communist Europe. Dudley, Mass.: Peeters, 2003.

Formicola, Jo Renee, "Recalibrating U.S. Catholic Church-State Relations: The Effects of Clerical Sexual Abuse.” Journal of Church \& State 58, no. 2 (2016): 307-330;

Forray R. Katalin, "Fiatalkorú bűnözés és vallásosság. Vizsgálatok a bűnöző fiatalok vallásosságáról és a preventív vallási nevelés kilátásai” [Juvenile delinquency and religion. Investigations on the Religion of Criminal Young People and Prospects for Preventive Religious Education], Educatio 1, no. 1 (1992): 158-159.

Iannaccone, Laurence R., "Religious Extremism: Origins and Consequences.” Contemporary Jewry 20, no. 1 (1999): 8-29.

Kinda István, “Hívők: Egyház és szekta hatása egy székely falu cigány lakosságára” [Believers. The effect of the Church and of the Sect on the Gypsy population of a Székely village]. Mediárium: társadalom - egyház kommunikáció 6, 3-4. (2008): 16-32.

Lehrer, Evelyn L., and Carmel U. Chiswick, “Religion as a Determinant of Marital Stability.” Demography 30, no. 3 (1993): 385-404.

Liebman, Charles S., “Extremism as a Religious Norm.” Journal for the Scientific Study of Religion 22, no. 1, (1983): 75-86.

Lugosi Győző, "Szekták, kultuszok, (már nem is annyira) új vallási mozgalmak: Szcientológia és globalizáció" [Sects, cults and (not so new) religious movements: Scientology and globalization]. Eszmélet 29, no. 2 (2017): 190211.;

Maynard, Shelly, "Szélsőséges mozgalmak és az egyház Amerikában” [Extreme movements and church in America], Lelkipásztor: evangélikus lelkészi szakfolyóirat (The Pastor) 12, no. 6 (1971): 358-360.

McPhillips, Kathleen, "The Church, the Commission and the Truth: Inside the NSW Special Inquiry into Child Sexual Abuse." Journal for the Academic Study of Religion 29, no. 1 (2016): 30-51.

Mezei Andrea, “Szekta és egyház a rendszerváltás után” [Sect and Church after the change of regime], Társadalmi Szemle (Social Review)49, no. 3 (1994): 44-53.

Omelicheva, Mariya Y., "The Ethnic Dimension of Religious Extremism and Terrorism in Central Asia." International Political Science Review/Revue internationale de science politique 31, no. 2 (2010): 167-186.

Papp Ferenc, "Igaz-e, hogy nem szekta a Hit Gyülekezete?" [Is it true that the Faith Church is not a sect?]. Távlatok: világnézet, lelkiség, kultúra 4, no. 1 (1996): 470-476.

Piotrowski, Suzanne J., and Alex Ingrams, "Linking Corruption with Institutional Failure, Terrorism, and Religious Extremism.” Public Administration Review 76, no. 2 (2016): 360-363.

Rabasa, Angel, and John Haseman, The Military and Democracy in Indonesia: Challenges, Politics, and Power. Jakarta: RAND Corporation, 2002. 
Rixer Ádám, “Az állam és a vallási közösségek kapcsolata a mai Magyarországon: A vallási közösségek nyilvántartása és pénzügyei a jogi szabályozás tükrében" [The Relationship of the State with the Religious Communities in Present Day Hungary Records and finances of religious communities in the light of legal regulations]. Államtudományi Mühelytanulmányok 2, no. 1 (2017): 1-42.

Rixer Ádám, "A hatásvizsgálatok jelentősége és egyes szempontjai a vallási szervezetek szabályozása körében" [The importance of impact assessments and some aspects of regulating religious organizations]. Kodifikáció 2, no 1 (2013): 91-102.

Rixer Ádám, “A vallás fogalmáról” [About the concept of religion]. Jogelméleti Szemle 12, no. 4 (2011): 1-8.

Stephen J. Rosetti, “Bátor szembenézés: Hatékony fellépés a gyermekek szexuális kihasználóival szemben” [Brave facing: An Effective action against sexual exploitation of children], Korunk 32, no. 4 (2012): 99-106.

Schanda Balázs, “A vallásszabadság és a lelkiismeret szabadsága” [Freedom of religion and freedom of conscience]. In Alkotmányjog - Alapjogok [Constitutional Law - Fundamental Rights], edited by Schanda Balázs and Balogh Zsolt, 141-169. Budapest: PPKE JÁK, 2011,

Stark, Rodney, and William S. Bainbridge, "Towards a Theory of Religion: Religious Commitment." Journal for the Scientific Study of Religion 19, no. 1 (1980): 114-128.

Tarsoly Eszter, "A szcientológia keresztyén szemmel” [Scientology with Christian eyes], Sárospataki füzetek (Booklets of Sárospatak) 15, no. 2 (2011): 135-146.

Tusckhova, Julia Valerijevna, "ISIS and Al-Qaeda as the Determinants of Religious Extremism in the UK." Society: Politics, Economics, Law 6, no. 8 (2017): 1-4. 